\title{
Hudud Jarimah For Business Crime Khamar And The Like (Comparative Study Qanun Aceh And Qanun The Syari'ah Crime At Brunei Darussalam)
}

\author{
Dr (Cand). Muhammad Nasir, SH., MH Prof. Dr. Alvi Syahrin, SH, MS ,Prof. \\ Dr. H. Hasballah Thaib, MA,Prof. Dr. Suhaidi, SH, MH \\ (Legal science doctoral student, Faculty of Law, University of Sumatera Utara, Medan, Indonesia)
}

\begin{abstract}
This paper analyzes the comparatively jarimah hudud for criminal khamar Aceh province that adopts European law Continental, with the State of Brunei Darussalam which adheres to the legal system of Anglo-Saxon is a very interesting thing because the two countries with different backgrounds legal system but can apply the legal system Islam in the enforcement of criminal law, whether hudud, qisas criminal offense / diyat or ta'zir. Results of analysis of the differences and similarities in the understanding and application of sanctions for the perpetrators of criminal acts relating to the liquor like. The method used is content analysis (content analysis) of the reference data to the issues discussed. Both systems jinayat adopted by both countries / regions that have the advantages that can be dikembang by both countries / areas to achieve legal stability in each of the area.
\end{abstract}

Keywords: Hudud, Ta'zir.

\section{INTRODUCTION}

Syar'iyah Court of Justice is the institution of Islamic Shari'ah in Aceh as the development of the Religious inaugurated on March 4, 2003 Miladiyah coincide with the date of 1 Muharram 1424 Hijri by Supreme Court Chief Justice Bagir Manan, attended by Minister of the Interior Sabarno, Minister of Religious Affairs Said Agil Husin Almunawar and Minister of Justice and human rights Yusril Ihza MahendraThe authority of the Court Syar'iyah is as stipulated in Law No. 71989 Religious Courts and Law No. 3 of 2006 on the Amendment of Act No. 7 Year 1989 About the Religious Courts. Coupled with the case jinayat consisting of Qanun 12 Year 2003 concerning Khamar, Qanun 13 Year 2003 on Maisir (gambling) and Qanun 142003 On Seclusion (nasty)Comparison criminal system in Aceh province with the country Brunei least based on several reasons; First, Court Syar'iyah in the province of Aceh and Brunei Darussalam is a juridical instrument of both countries / regions were granted by the Government of Indonesia to the province and the country Brunei Darussalam which is a criminal offense jinayat constitution in particular. Second, implementation of the law jinayat an injunction in court to Law Syar'iyah, is a must in both countries / regions in cases relating to jinayat. Third, the implementation of criminal sanctions based on Islamic law tends to be different in these two areas when using the same source, namely the Shari'ah by primary guidance is the Qur'an, hadith, ijma 'and qiyas.

The legal system adopted by the two regions / countries is certainly very different from the province of Aceh, which is part of the republic of Indonesia adopts a European Legal Continental, which developed in the European countries, also called the Civil Law, which is the Roman law, the law says Roman because the legal system is derived from the codification of the laws of the Roman empire during the 5th century Government Justinian (527-565 AD), the codification of the law is a collection of various rules of law which was before the Justinian called the Corpus Juris Civilis, the law codified. Corpus Juris Civilis used as a basic principle in the formulation and codification of law in continental European countries such as Germany, the Netherlands, France, Italy, Latin America, Asia, including Indonesia, which was brought by the Dutch and is still applied today. In general it is according to this system every law must be codified to be applied within a country. Country Brunei Darussalam adopts Law Anglo Saxon, First developed in the UK, known as the Common Law or Unwriten Law (common law), the legal system is adopted in the member countries of Commonwealth, North America, Canada, United States ${ }^{1}$, also of Brunei Darussalam brought by the British and is still applied until now

Qanun jinayat Brunei Darussalam adheres to the principle of territoriality in which every person is Muslim or other than Islam, is in the state of Brunei Darussalam in violation of Qanun jinayat will be subject to the law jinayat, or residents of Brunei Darussalam are outside the State of Brunei violating Qanun Jinayat

1 http://wahidabdurahman.blogdetik.com/?p=10\#more-10 (access on, Maret, 20 2015). 
Brunei Darussalam, the applicable law jinayat Brunei and in Brunei jinayat not leave unless the court Syar'yah judicial selection ${ }^{2}$, but more interesting is that although Qanun jinayat applied to all levels of society, for users of intoxicating drinks only Muslims are subject to hudud punishment is flogging 40 times for first offenders, repeat two times whipped 80 times, repeated a third time caned 80 times and jailed a maximum of two (2) years.

Qanun jinayat in Aceh that the legal system is essentially a system of European Law Continental, then the general law should be codified to be applied in a country or region, while the principle was adopted of personality and territoriality where qanuns jinayat only applicable to Muslims only, while that not many different Islam may choose Qanun Justice Jinayat or country. Acehnese people who commit criminal acts outside Aceh jinayat positive law is enforced as the Criminal Code. Whereas the corresponding penalties this paper is to drink wine Muslims convicted of hudud, whipped 40 times, if repeated lashes plus 1/3 (14) times. While the authority of the court is a matter jinayat Syar'iyah that has in Qanun ${ }^{3}$.Comparison between the province of Aceh as part of Indonesia adopts a European law Continental, with the State of Brunei Darussalam which adheres to the legal system of Anglo-Saxon is a very interesting thing because the two countries with different backgrounds legal system but have similarities in implementing the Islamic legal system, namely the Court shar 'Yeah, although different in using the principles and sanctions as the focus of this study is jinayah alcohol, which is the interest to be studied. The formulation of the problem to be served the author in this paper is the How is the setting khamar according to Islamic legal system, how regulation khamar Qanun AcehIndonesia and Brunei Darussalam, What are the differences and similarities settings khamar both the system adopted by the Province of Aceh-Indonesia and Brunei Darussalam.

\section{KHAMAR SETTINGS WITHIN THE ISLAMIC LEGAL SYSTEM}

Khamar from Arabic means covering. Kind of intoxicating drinks (covering health reason). Islam regards wine as one of the key symptoms of crime, such as blocking someone's remembrance of Allah, hinder a person's prayers and consume liquor is Satanic. Therefore, khamar both the essence and the user, expressly forbidden in the Qur'an and the Sunnah of the Prophet SAW. At the beginning of Islam khamar has become a habit or living part of Arab society, the prohibition is done gradually. Gradually ban known as the following verse:A group of friends including Umar, Muadh ibn Jabal and asked the Prophet about wine. Then there came the revelation that is revealed in the Qur'an in surah Al-Baqarah verse 219 which means, "They ask thee concerning wine and gambling. Say them even there is great sin, and some benefits for men, but the sin is greater than its benefits both ... " In this verse there is no prohibition for the content of the verse mentions only form of information khamar sin is greater than the benefitsIn the next stage, dropped the letter al Maidah verse 90 which means: "O those who believe, in fact (drinking) alcohol, gambling, (sacrifice to) idols, gambled with the fate of the arrows are abominations including Satanic. So, stay away from the deeds that ye may prosper.'. In this verse, there have been demands for leave to drink alcohol, because it is included indecency or Satanic

When there was a man who was drunk by drinking wine prayers and reciting surat Al Kafirun repeatedly but not right, then down the revelation contained in the letter of An-Nisa, verse 43 which means: "O you who believe, do not pray, being you drunk, so that you understand what you're saying ... " in this verse has increased interdiction should not offer prayers, when prayer is the pillar of religion, is an obligation for all Muslims were perfect.Then the Prophet said in Hadith narrated by at-Tabarani from Abdullah ibn Umar that means, "Khamar is the mother of crime and the greatest of major sins, and those who drink alcohol, it will leave prayers and fall (screwed) mother and aunt". the Prophet also describe people who drink alcohol like people who worship idols, meaning that it has lost its Islamic. (Reported by Ibn Majah from Abu Hurairah). Due to the great sin from drinking alcohol, then that gets anathema or punishment not only those who drink alcohol, but also those involved with alcohol, such as those who serve, sell, supply, create, cultivate and enjoy the wine sales results ${ }^{4}$.

Hadith Prophet Muhammad: From Ibni Umar RA. that the Prophet SAW said, 'Everything that's intoxicating wine and all kinds of wine that haram.` (HR. Muslim and Ad-Daruquthuny). Another Hadith the Prophet SAW said, 'Everything is intoxicating wine and everything that heady haram` law. (HR. Ahmad and

2 News Kingdom of Article 3 (1) Rather it is intended to manifest the opposite inside it, this command let subject to Muslims and non-Muslims. Article (2) Every person let liable to punishment under this, and not in others for any act or contrary to the heritage designation designation under which he made a mistake in the State of Brunei Darussalam. Article (3) Any person may be discussed on a fault under the orders of this is done outside State of Brunei Darussalam let be treated according to the allotment-allotment this command for ubiquitous acts committed outside the State of Brunei Darussalam in the same way as if the deed has been done in the State of Brunei Darussalam.

3 Komariah Emong Sapardjaja, Supreme Court, paper, Qanun Aceh, Jakarta, March 7, 2012.

4 http://infokito.wordpress.com/2008/01/17/khamar/ (access on November, 24 2013) 
Ashhabussunan). Rasulullah SAW said, 'O people of Medina, Allah has lowered the prohibition of liquor. So who wrote this verse and still have it do not drink and do not also sell them. But just throw it in the streets of the city Madinah`. (Muslim) Ibn Abbas ra. that the Prophet SAW said, 'The real drinks are forbidden to drink the forbidden also aftersale`. (HR. Ahmad, Muslim, An-Nasai)Khamar often termed the liquor, but not just to drink, but all forms of usage so intoxicating as formerly known as opium or other ${ }^{5}$. perpetrators will in threatened hudud punishments. Islam provides limits as a condition for the implementation of hudud punishment for drink wine that understands, baligh, Muslims, not in a state that is forced, not in an emergency situation, know that it is using this thing. For Muslims khamar not classed helpful treasures, so that wiping is not mandatory but if khamar replace it belongs to non-Muslims, it shall replace it when destroyed or spilling. Hudud punishments for those who consumption khamar Rasul did not specify the amount but the friends set 40 times and there is also a set of 80 lashes, as is mentioned by Ali bin Abi Talib, which means: "The Messenger punishing whip 40 times to drink wine and Abubakar also 40 times, while Umar 80 times all of it is Sunnah and this is what I prefer ${ }^{6}$.

\section{REGULATION KHAMAR QANUN ACEH AND NEGARA BRUNEI DARUSSALAM}

After the enactment of the Aceh Government Law No. 11 Year 2006 Article 125, reaffirmed the enactment of Islamic law in Aceh, as well as paragraph (1), Islamic Sharia implemented in Aceh include aqidah, Shari'ah and morals, (2), Syari'at Islam as described in paragraph (1) includes worship, ahwal al syakhshiyah (family law), muamalah (civil law), jinayah (criminal law), qadha (justice), tarbiyah (education), da'wa, greatness, and defense Islam. (3) Further provisions concerning the implementation of sharia law as referred to in paragraph (1) shall be regulated by Aceh Qanun. Reaffirmation of the commitment of the government of Aceh and district / city regarding the implementation of sharia law in Aceh which is now changed to be "Aceh Province" set out in Article 127 Paragraph (1), "The Aceh Government and district / city is responsible for organizing the implementation of shariah 'at Islam "and become an authority in the enforcement court Syar'iyah.

Presidential Decree No. 11 Year 2003 regarding the Supreme Court Syar'iyah Syar'iyah and province in Nanggroe Aceh Darussalam in Article 1 states: (1) Courts that already exist in the province of Aceh converted into Syar'iyah Court. (2) Religious High Court Banda Aceh converted into Syar'iyah Court of Nanggroe Aceh Darussalam, hereinafter in this Presidential Decree referred to the Court Syar'iyah ProvinceAnd thereafter Article 2 reads: (1) The Supreme Court of the Regional Law Syar'iyah as mentioned in Article 1 (2) is an area of the former Law Religious Courts concerned. (2) Regional Law Syar'iyah Provincial Court as referred to in Article 1 (3) is an area of the Law of the former High Court Religion Banda AcehThus, the relative power of Supreme Court of Syar'iyah in Aceh province is covering an area of two levels where the Court Syar'iyah it is. While Syar'iyah Provincial Court, jurisdiction covers the entire province. For Syar'iyah Court and Provincial Court Syar'iyah is a change from the Religious Courts in Aceh.Justice Islamic Shari'a in Aceh is part of the national justice system in the religious courts were carried out by the Court Syar'iyah free from the influence of any party. Syar'iyah Court is a court for any person who is Muslim and is located in Aceh.The Supreme Court consists of Syar'iyah Syar'iyah Regency / City as a court of first instance and the Court Syar'iyah Aceh as a court of appeal. Syar'iyah Court judges are appointed and dismissed by the President upon the recommendation of the Chief Justice.Syar'iyah Court has authority to examine, hear, decide, and resolve cases covering the fields Ahwal Al-Syakhsiyah (family law), Muamalah (civil law), and Jinayah (criminal law), which is based on Islamic shariah. Provisions on the field Ahwal Al-Syakhsiyah (family law), Muamalah (civil law), and Jinayah (criminal law) is regulated by Aceh QanunCourt Decision Syar'iyah Aceh may be requested cassation to the Supreme Court. The procedural law applicable in the Court Syar'iyah is a procedural law regulated in Aceh Qanun. Syar'iyah dispute of authority between the Court and other courts in the judicial environment under the authority of the Supreme Court on the first and last level.Everyone that religion is not Islam acts jinayah are not regulated in the Criminal Justice Act or the criminal provisions beyond the Code of Criminal jinayah applicable law. The task of inquiry and investigation to the enforcement of Islamic Shariah Court has the authority Syar'iyah along the jinayah made by police and civil servant investigators ${ }^{7}$.In terms of the application of penalties for perpetrators of alcohol, Syar'iyah court, guided by Islamic law. Islamic Shariah is implemented in Aceh in general embraced the theory of Islamic law disari of al-Qur-an with the principle of "all that is helpful to be allowed and all that harms banned, do not give rise to kemudaratan and do not become victims

5 Sulaiman Rasyid, Fiqh Islam, (Jakarta; Athahiriyyah, 1978), P.415.

6 Haji Awang Abdul Aziz bin Juned, the State Mufti of Brunei Darussalam kingdom, Qanun Crime Syar'iah an introduction, (Brunei: Position Mufti kingdom, Position Minister of Brunei Darussalam, 2013 ), P. 140.

${ }^{7}$ http://id.wikipedia.org/wiki/Pemerintahan_Aceh 
kemudaratan, hazards must be eliminated" ${ }^{\prime 8}$ covers the field aqidah, Syar'iyah, and morals. The Islamic Shari'ah includes worship, ahwal alsyakhshiyah (family law), muamalah (civil law), jinayah (criminal law), making up '(justice), tarbiyah (education), da'wa, greatness, and the defense of Islam. Implementing provisions of Islamic Shari'a shall be regulated by Aceh Qanun.In Aceh for perpetrator khamar as stated in the terms 'Uqubat Qanun No. 12 of 2003 regarding wine beverages and the like are:Article 26 paragraph (1) Every person Muslims consumption drinks wine and the like were threatened with 'uqubat hudud 40 lashes. Paragraph (2) Any person or legal entity / entities or participate produce, provide, sell, post, distribute, distributing, transporting, storing, stockpiling, trade, give away, promote responsible drinking wine and the like or Article 8, any person who has business license hotels, guesthouses, inns, guesthouses, bars, restaurants, coffee shops, restaurants, shops, kiosks, and other places that legalize the provision of drinks khamar and the like, is threatened with 'uqubat ta'zir be a maximum confinement of 1 year minimum 3 months and / or a maximum fine of Rp. 75 million, at least 25 million,Article 30, the terms 'uqubat if conducted by a legal entity / entities, then the' uqubatnya meted out to the person in charge, if there is a connection with the business activities 'uqubatnya besides fines are also imposed' uqubat administration to suspend or revoke the business license has been granted.State of Brunei Darussalam through the Sultan Hasanah Bolkiah has expressed formally impose Islamic law in the country starting May 1, 2014. This policy Sultan then invited harsh criticism of various human rights groups called the move internationally with Brunei as a step backwards for human rights. Responding to the criticism, Sultan Hasanah Bolkiah explained that Islamic Law enacted precisely to protect community from injustice court of law.The justice system in the State of Brunei Darussalam currently has two court that justice is based on English law and justice based on Shari'a previously authority limited to family problems. This time Brunei has ratified apply sharia law to establish a three-stage application of the law that is the first stage of implementing jinayat ta'zir penalty, the second phase of implementing hudud punishment but not limited to the death penalty, the third stage will impose hudud punishments completely every jinayat relating to hudud, Qisas and ta'zir ${ }^{9}$.Brunei Darussalam interpret liquor with "Arak", ie all sorts of objects that intoxicating either little or much and drunk or not remains subject to the Hadd punishment, the offender was first to be whipped 40 times, repeating the second time whipped 80 times, repeated three times whipped 80 plus a maximum of 2 years in prison and also when the next repeat again. Requirements to be sentenced to hadd is the recognition of the drinker or witnessed by at least two people, in addition to the recognition of the perpetrator also confidence consider judges with witness testimony, it is as the content of Article 104 paragraph (1) and (2) a second message of the kingdom CourantHowever, in paragraph (3) different penalties due to different testimonies that besides the recognition or witnessed by a minimum of two people or by using wine to put in drinks or food, this is not dihadd, but if it proves to be fined $\$ 4,000$ or jailed for up to one year or even both of them if repeated a second time will be fined up to $\$ 8,000$ or imprisonment up to 2 years or both of themParagraph (4) Every Muslim who manufacture, sell, advertise, serve, offer, reward, display, possess, store, buy, classified to jinayat, if it is proven then sentenced to a fine not exceeding $\$ 8,000$ or imprisonment for up to 2 years, or it could be applied to both both of them.Paragraph (5) Any non-Muslims who drink wine or intoxicating publicly commits jinayah and if proven, dikum maximum fine of $\$ 8,000$ or imprisonment for up to 2 years, or both of themParagraph (6) NonMuslims who sell, advertise, serve, or display the Muslims of jinayah punished with a maximum penalty of $\$$ 8,000 , or imprisonment for up to 2 years, or both of them.Article 105 paragraph (1) Every Muslim who cause people drink wine, or wear it or produced it has done jinayah, if proven, was fined $\$ 4,000$, or imprisonment for up to one year, or both of them.Paragraph (2) Non-Muslims trying to plunge the people of Islam to jinayah wine or alcohol, then it has done jinayah, if it is proved they will be fined a maximum of $\$ 4,000$, or jailed for up to one year, or both of them. Article 106 paragraph (1) any person who participated did as Article 104 paragraph (1) means has done jinayah, if proven, would punished a maximum fine of $\$ 8,000$, or imprisonment for up to 2 years, or both of them, while participating in performing as paragraph (3), (4), (5) or (6) means it has been doing jinayah, if proven, would be sentenced to a maximum fine of $\$ 4,000$, or imprisonment for a maximum of one year or do both

\section{DIFFERENCES AND SIMILARITIES KHAMAR SETTING} ACEH-INDONESIA AND BRUNEI DARUSSALAM

Islamic law is universal, meaning that applies equally to all followers of Islam everywhere, not limited to one's nationality. The applicability of Islamic law in Indonesia is influenced by customary law. This is caused by the Indonesian history shows that every region has their customs laws as their positive law. In their

\footnotetext{
8 Ahmad Ali, Menguak Teori Hukum dan Teori Peradilan, (Brenada Media Group, Jakarta, 2012),
} P.216.

$9 \quad$ Hadiati Binti Abdul Hadi. 
traditional social institutions, customary law based on the magical-religious principle, which is the influence of Islamic law, changing rule of morals into legal norms which entered into force in their communities

Aceh is an area that has a distinctive reason to apply Islamic law as their positive law. Legislation in force in Aceh based on Shari'a. This is influenced by history, that Islam arrived in Indonesia starts Aceh, the northern coast of the island of Sumatra, which was then experiencing rapid development. The Islamic law then gives a great influence to the customary law in Aceh, so that positive law Aceh bore the nuances of Islamic law.

Due to the Acehnese people in general have to know and understand that the implementation of Shari'ah Islamic law that has been poured into Qanun is not a new thing among the Acehnese, but if it is contrary to the custom in the community although said to be from the Islamic shariah will be denied even being friction that prolonged, as a time when the first peace agreement between Indonesia and GAM, as an effort to compensate the victims as a result of prolonged conflict then the resulting efforts of the government to pay "diyat" to all victims conflict. But in general community reject it because it is not consistent with the theory that they are able to understand the concept in accordance with the Shari'ahIn the State of Brunei Darussalam Laws have been enacted in the National Jinayat, Has had the prosecutor Sharia. Qanun Jinayat applies to everyone residing in the State of Brunei Darussalam both Muslims and non-Muslims. Adheres to the principle of personality means any person violating jinayat Brunei remains subject to the provisions of jinayat although it is outside Brunei, or violate Jinayat outside Brunei. About drink wine Brunei does not penalize non season consumption wine or liquor, but if consumption in public will be punished by fine or imprisonment or both of themImplementation of Islamic Shariah in Aceh is limited in the scope of the national legal system and should be in the national judicial system, it has been a drawback thus not being free in establishing a legal conclusion of the new problems arise. An understanding of sharia law are inadequate among the leaders, both formal and non-formal, both engaged in social organizations and political organizations, including those that deal directly with the authority to design regulations relating to Islamic law. Quality resources very limited so difficult to obtain precise relative power has mastered the problems arising, also for enforcers in this connection only judge who has been equipped with Shari'ah judges as the police, prosecutors are not yet fully equipped with the knowledge Shari'a. A different understanding among scholars or scholars of Shari'a coverage will be executed and also still lacking determination on responsibility for such implementation which become the responsibility of the government, public or private ${ }^{10}$. Moreover, differences of shari'ah tendency to be run like a trend different from the Salaf sect is also different with tajdid ${ }^{11}$.

\section{BIBLIOGRAPHY}

[1] Ahmad Ali, Menguak Teori Hukum dan Teori Peradilan, (Brenada Media Group, Jakarta, 2012).

[2] Al-Yasa' Abubakar, Syari'at Islam di Aceh, Paradikma, Kebijakan dan Kegiatan, (Banda Aceh: Dinas Syari'at Islam Aceh, 2008).

[3] Haji Awang Abdul Aziz bin Juned, the State Mufti of Brunei Darussalam kingdom, Qanun CrimeSyar'iah an introduction, (Brunei: Position Mufti kingdom, Position Minister of Brunei Darussalam, 2013).

[4] Komariah Emong Sapardjaja, Supreme Court, paper, Qanun Aceh, Jakarta, March 7, 2012.

[5] Sulaiman Rasyid, Fiqh Islam, (Jakarta; Athahiriyyah, 1978).

[6] http://id.wikipedia.org/wiki/Pemerintahan_Aceh

[7] http://infokito.wordpress.com/2008/01/17/khamar/ (access on November, 24 2013)

[8] http://wahidabdurahman.blogdetik.com/?p=10\#more-10 (access on, Maret, 20 2015).

10 Al-Yasa' Abubakar, Syari'at Islam di Aceh, Paradikma, Kebijakan dan Kegiatan, (Banda Aceh: Dinas Syari'at Islam Aceh, 2008), P. 121.

11 Ibid, P. 198. 